\title{
Do Endangered Razorback Suckers Have Poor Larval Escape Performance Relative to Introduced Rainbow Trout?
}

\author{
Heather M. Wesp and Alice C. GibB* \\ Department of Biological Sciences, Northern Arizona University, \\ Flagstaff, Arizona 86011-5640, USA
}

\begin{abstract}
Poor recruitment has generated the hypothesis that the endangered razorback sucker Xyrauchen texanus is particularly vulnerable to predation early in its life history. We compared the escape responses of razorback suckers, which are adapted to the historically warm waters of the Colorado River, with those of rainbow trout Oncorhynchus mykiss, an introduced coldwater species, throughout early development at water temperatures of $12^{\circ} \mathrm{C}$ and $18^{\circ} \mathrm{C}$. We quantified escape performance using maximum velocity, acceleration, and time to maximum velocity and acceleration. Both species showed complete temperature compensation for escape performance; individuals reared at $12^{\circ} \mathrm{C}$ performed as well as those reared at $18^{\circ} \mathrm{C}$. Performance was also similar between species, although two variables exhibited a species $\times$ size interaction. Small razorback suckers were faster (greater maximum velocity and acceleration) than small rainbow trout, while large larvae performed similarly. We also determined that razorback sucker larval escape performance falls within the range reported for other fishes. Therefore, we conclude that razorback suckers do not have "poor" escape performance and that temperature does not directly cause decreased performance. However, a cold temperature reduces growth rates and delays razorback suckers' attainment of a "predator-proof" size. Small larvae are also more likely to perform uncoordinated, ineffective escape responses. Hence, razorback sucker performance is indirectly diminished by temperature.
\end{abstract}

The endangered razorback sucker Xyrauchen texanus is endemic to the Colorado River system (Tyus et al. 1982; Minckley 1983). Once abundant and widely distributed, the razorback sucker is now limited to scattered populations in the upper and lower Colorado River basin (Minckley et al. 1991). The remaining wild populations of razorback suckers appear to be relict subpopulations of very old individuals, ones that are 30 years old or older (Minckley 1983; McCarthy 1986; McCarthy and Minckley 1987). These populations are reproducing in the wild (Bozek 1984; Marsh and Langhorst 1988; Mueller 1989), but larval recruitment appears to be severely limited (Minckley 1983; Marsh and Minckley 1989).

The proximate cause of limited recruitment remains unknown, but predation on razorback sucker early life history stages by introduced fishes has been proposed as the single most important factor (Minckley et al. 1991). In a series of experiments in the Lake Mohave portion of the Colorado River, razorback sucker larvae showed high survival rates $(80 \%)$ when predators were excluded (Minckley et al. 1991). The ability of larvae to persist and grow when predators are absent supports the hypothesis that predation is the major

* Corresponding author: Alice.Gibb@nau.edu

Received April 19, 2002; accepted April 29, 2003 factor responsible for the limited recruitment of the razorback sucker, although other factors (habitat loss, physical changes to the environment, etc.) certainly will also affect survival.

Historically, the Colorado River supported a limited number of piscivorous fish (Johnson et al. 1993), only one fish (the endemic Colorado pikeminnow Ptychocheilus lucius) being known to prey on adult razorback suckers (Minckley et al. 1991). As such, selection for escape performance may have been weak. Currently, at least five introduced fish predators are known to prey on the razorback sucker: striped bass Morone saxatilis, largemouth bass Micropterus salmoides, channel catfish Ictalurus punctatus, flathead catfish Pylodictis olivaris, and green sunfish Lepomis cyanellus (Marsh and Brooks 1989; Minckley et al. 1991; Johnson et al. 1993). The introduction of these and other exotic fish species has drastically changed the predation rates experienced by the razorback sucker in the Colorado River.

Many fish species use escape responses as a defense against predators (e.g., Webb and Corolla 1981). The escape response typically exhibited by fish is a rapid acceleration involving bending about the center of mass followed by a single propulsive tail stroke and burst swimming (Figure 1). These escape responses (or "C-starts") have been shown to be effective in allowing larval fish to escape 


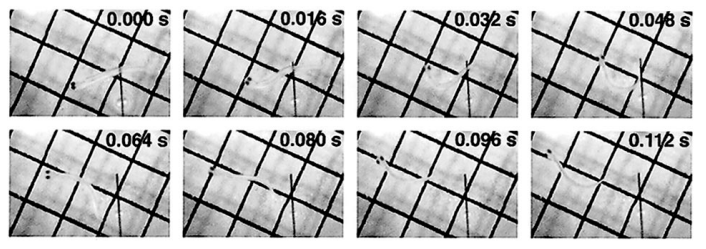

FIGURE 1.-These panels depict a razorback sucker larva being stimulated to perform an escape response. A $0.5-\mathrm{cm}$ grid is shown beneath the filming chamber for scale. Time from the beginning of the escape response is given on each panel in seconds. The first four panels depict stage 1 (the C-stage) and the next two panels depict stage 2 (the $\mathrm{S}$-stage); the final two panels depict stage 3 (free swimming).

attacks by both invertebrate (Seale and Binkowski 1988; Horn et al. 1994) and vertebrate predators (Webb 1981; Katzir and Camhi 1993). Correlations between escape performance and survival have been suggested or demonstrated by several studies (Swain 1992a, 1992b; Andraso 1997; Temple and Johnston 1998), making studies of escape performance a relevant tool for evaluating the potential effects of predation on razorback sucker larvae. We hypothesized that the razorback sucker has poor escape response performance (relative to other fishes) because it evolved in a habitat with few natural predators.

The rainbow trout Oncorhynchus mykiss is cultured and constantly seeded into the Colorado River, making it one of the most abundant introduced fish species. In addition, rainbow trout reproduce and persist in localities historically populated by razorback suckers (Vanicek et al. 1970; Minckley et al. 1991). For example, after the Flaming Gorge Dam in Utah closed in the 1960s, rainbow trout and razorback suckers co-occurred in the habitat below the dam for several years (Vanicek et al. 1970). Today the rainbow trout thrives in the Colorado River below Flaming Gorge Dam, but the razorback sucker has been extirpated. This suggests that the razorback sucker was at a disadvantage relative to the rainbow trout in this modified habitat. In addition, both juvenile and adult trout are territorial, opportunistic feeders (Hartman 1965; Jenkins 1969) that have been observed preying on another southwestern native, the Little Colorado spinedace Lepidomeda vitatta even in the presence of abundant macroinvertebrate prey (Blinn et al. 1993). Thus, the rainbow trout serves as a useful model of an introduced coldwater species because it reproduces successfully in areas historically inhabited by the razorback sucker and is a potential predator on young razorback suckers.
Abiotic variables such as water temperature also may contribute to limited razorback sucker recruitment. The addition of dams has dramatically altered the temperature of the Colorado River (e.g., Vanicek et al. 1970), and future proposed development projects in the upper Colorado River basin could further affect river temperature (Bulkley and Pimentel 1983; Childs and Clarkson 1996; Clarkson and Childs 2000). Historically, razorback sucker larvae were found along shallow shorelines, in embayments along sandbars, or in tributary mouths in water temperatures ranging from $21.7^{\circ} \mathrm{C}$ to $24.4^{\circ} \mathrm{C}$ (Sigler and Sigler 1996). Current tailwater temperatures are approximately $10^{\circ} \mathrm{C}$ during the spring-summer reproductive period (Childs and Clarkson 1996). The physiological processes underlying escape response performance (diffusion rates, enzyme reaction rates, etc.) are known to be temperature dependent (for a review, see Bennett 1990). Therefore, reduced water temperature may cause reduced escape performance in the razorback sucker.

The goal of this study was to assess razorback sucker escape performance to determine whether it may have contributed to their failure to thrive under current Colorado River conditions. To do this, we addressed two specific questions: (1) does decreased water temperature reduce larval and juvenile escape response performance in the razorback sucker? and (2) do razorback sucker larvae and juveniles have poor escape performance relative to rainbow trout larvae and juveniles? To answer these questions, we quantified escape performance in razorback sucker and rainbow trout early life history stages at two water temperatures. We hypothesized that (1) escape performance would be reduced for both species in colder water because of the direct physiological effects of temperature and (2) razorback sucker escape performance would be poor relative to rainbow trout escape performance because the razorback sucker evolved in a reduced-predation environment. Finally, we compared our data for razorback sucker larvae with those from previous studies to determine whether razorback suckers have poor escape performance relative to the larvae of other species.

\section{Methods}

Study species.-Razorback sucker eggs were obtained from the Willow Beach National Fish Hatchery, Arizona, in March 2000. Rainbow trout eggs were obtained from the Lost River Trout Hatchery, Idaho, in May 2000. The eggs were divided among eight tanks $(43 \mathrm{~cm}$ long $\times 26 \mathrm{~cm}$ 
wide $\times 15 \mathrm{~cm}$ deep) in the Research Annex at Northern Arizona University with a photoperiod of $14 \mathrm{~h}: 10 \mathrm{~h}$ light : dark. Each tank contained recirculated and filtered freshwater. Four tanks were maintained at $12^{\circ} \mathrm{C}$ and four at $18^{\circ} \mathrm{C}$. The $12^{\circ} \mathrm{C}$ and $18^{\circ} \mathrm{C}$ treatments were chosen (rather than more extreme temperatures) because razorback suckers approach a lower temperature limit at $12^{\circ} \mathrm{C}$ and disease becomes prevalent in rainbow trout above $18^{\circ} \mathrm{C}$. In addition, these temperatures approximate the change from historic to current Colorado River water temperatures and allow comparisons with published data for the larvae of other fish species.

Fish were reared for the duration of larval development and into early juvenile stages (approximately 2 months) and were fed once per day after they began to swim up off the bottom of the tank in search of food. Razorback sucker larvae initially received live nauplii of brine shrimp Artemia spp. and were later fed a mixture (obtained from the Willow Beach National Fish Hatchery) of dried fish food containing plankton flakes, spirulina flakes, brine shrimp flakes, krill flakes, Encapulon, Cyclop-eeze, and artificial plankton (microencapsulated protein). Rainbow trout larvae also initially received live Artemia nauplii and were later fed pellets of Dense Culture Food (obtained from Aquatic Ecosystems, Inc.). These diets were chosen based on the recommendation of a fishery biologist (Chester Figiel, U.S. Fish and Wildlife Service, personal communication) to maximize the growth and survival of each species. Due to temperature-related mortality in the $12^{\circ} \mathrm{C}$ razorback sucker treatment, we obtained additional eggs from the Willow Beach National Fish Hatchery in March 2001. These eggs were acclimated at $1^{\circ} \mathrm{C}$ per day until the water temperature was $12^{\circ} \mathrm{C}$ in an effort to reduce egg mortality (although mortality remained high). Larval and juvenile fish were maintained as described above.

Experimental design and analysis._Each fish was imaged at 500 frames per second using a highspeed digital imaging system. The camera was mounted above the testing chamber with the camera mount perpendicular to and the lens parallel with the water surface. A single fish was placed in the circular, glass testing chamber $(6 \mathrm{~cm}$ in diameter $\times 2 \mathrm{~cm}$ deep or $10 \mathrm{~cm}$ in diameter $\times 6 \mathrm{~cm}$ deep) and allowed to acclimate for at least $5 \mathrm{~min}$. A $0.5-\mathrm{cm}$ grid was placed below the testing chamber for scale and the chamber was illuminated with a fiber-optic light. Water temperature was held constant at the rearing temperature $\left(12^{\circ} \mathrm{C}\right.$ or $\left.18^{\circ} \mathrm{C}\right)$ by a water bath connected to a recirculating water chiller. Each escape response was elicited using a small blunt probe through tactile stimulation of the fish's head, body, or tail. Three to eight responses per individual ( $0.5-1.5 \mathrm{~h}$ trial time) were recorded as a digital movie. This process was repeated for 24 razorback suckers at $12^{\circ} \mathrm{C}$ and 39 at $18^{\circ} \mathrm{C}$. Similarly, 28 rainbow trout were tested at $12^{\circ} \mathrm{C}$ and 30 at $18^{\circ} \mathrm{C}$. The individuals included in both of these samples were selected from the rearing tanks at 2-d to 3-d intervals over a 70-d rearing period to represent an ontogenetic series.

After testing was complete, larvae were euthanatized with a $1 \%$ solution of MS-222 (3-aminobenzoic acid ethyl ester), preserved in $10 \%$ buffered formalin, and transferred to $70 \%$ ethanol. The following measurements-mass $(\mathrm{g})$, mass without yolk sac (g), mass without yolk sac and head $(\mathrm{g})$, length $(\mathrm{cm})$, and length without head $(\mathrm{cm})$ - were taken from the preserved specimens with digital calipers, an electronic balance, and a dissecting microscope. To determine whether the specimens had experienced significant shrinkage due to preservation, we compared the lengths measured from 20 preserved individuals of each species with the approximate lengths from digital images of the same individuals. There was an effect of preservation on total length (paired $t$-test, $P<0.05$ ) for razorback suckers and rainbow trout; specimens appeared to shrink by $8-9 \%$ of total length. This degree of shrinkage is similar to that reported for the larvae and juveniles of a range of other fish taxa (about 8\%; Hjörleifsson and Klein-MacPhee 1992). Thus, we used an equation developed by Hjörleifsson and Klein-MacPhee (1992) to correct for the effects of preservation on length and used the adjusted specimen lengths in comparisons with data from other studies. We were unable to assess changes in weight due to preservation; however, previous studies suggest that the larvae and juveniles of freshwater fishes initially gain weight when preserved but then lose it after $30 \mathrm{~d}$ so as to approach their original weight (Karjalainen 1992; Shields and Carlson 1996). These specimens were preserved for more than $30 \mathrm{~d}$ before being measured; as such, the wet weight of the preserved specimens should be similar to the prepreservation wet weight. In addition, if there are effects of preservation on weight, they should be the same for all of the specimens used in this study and should not affect inter-specific comparisons.

Three responses per fish were selected for preliminary analysis. Responses in which the fish was obscured by water movement or reflection or was partially off-screen were discarded. Generally, re- 
sponses could be divided into three stages (Weihs 1973; Hale 1999). In stage 1 (the C-stage), the fish bent to one side of the body about the center of mass, forming the traditional " $\mathrm{C}$ " shape. In stage 2 , sometimes called the S-stage, the fish bent in the opposite direction of the stage 1 bend and began moving away from its initial position with a propulsive tail stroke. When the tail stroke reached its maximum excursion on the opposite side of the body, stage 2 was completed. Stage 3 consisted of continued caudal fin swimming after stage 2 (Figure 1).

The single best escape response for each individual, determined by the fastest maximum velocity and/or shortest response duration, was selected for quantitative analysis. Sequential digital images from each escape response were imported into Didge Image Digitizing Software (Cullum 1999). A series of 11 evenly spaced points were placed longitudinally along the fish's body between the tip of the snout and the tail, dividing the fish into intervals of one-tenth of the total body length. The movements of the fish were quantified for each frame of the escape response in terms of these points. A total of 121 razorback sucker $(n=63)$ and rainbow trout $(n=58)$ escape responses were analyzed in this manner; each sample analyzed represented the best escape response for a particular individual.

Because calculations of velocities and accelerations of fish movement are affected by measurement error (Walker 1998), QuickSAND (Walker 1997) was used to determine velocity and acceleration by means of numerical differentiation algorithms. With this program, velocity and acceleration were calculated with a cubic-spline algorithm and an estimated error variance (VAL). This estimated error variance was used to mathematically remove the effects of digitizing error (in this case, the error generated because the pixel digitized is larger than the targeted point on the fish) from the data. The values used for VAL ranged from $5.0 \times 10^{-3} \mathrm{~cm}$ (approximately $1 / 4$ of a pixel) to $6.25 \times 10^{-4} \mathrm{~cm}(1 / 32$ of a pixel), depending on the size of the fish. Performance variables, including maximum velocity $(\mathrm{cm} / \mathrm{s})$, time to maximum velocity $(\mathrm{s})$, maximum acceleration $\left(\mathrm{cm} / \mathrm{s}^{2}\right)$, and time to maximum acceleration (s), were taken from the data for each individual after they had been processed with QuickSAND.

Statistical analysis.-All data exploration and statistical tests were performed with SuperANOVA or Statview. (SAS Institute 1998). Before we performed parametic statistical tests, we tested the data for normal distribution and homogeneity of variances. In all cases the data were normally distributed (Kolmogorov-Smirnov tests for goodness-of-fit, $P>0.05$ ) and homoscedastic (BoxScheffé tests for homogeneity of variances, $P>$ 0.05). We tested for potential effects of rearing temperature on fish size (mass) with a two-way analysis of co-variance (ANCOVA) using age (days after hatching) as a covariate. Because fish increase in size exponentially during development, mass was $\log _{10}$ transformed to allow a general linear model to be used in the analysis.

A second series of analyses was performed on four escape response performance variables (maximum velocity, maximum acceleration, and time to maximum velocity and acceleration). The size variable with the strongest scaling relationship with maximum velocity, namely, body mass after removal of the yolk sac (g), was chosen as the covariate for all size-dependent displacement and timing variables. (In fact, statistical analyses using total body mass $(\mathrm{g})$ or total fish length $(\mathrm{cm})$ versus performance variables produced similar results.) Because mass increases exponentially during development, body mass without the yolk sac and all performance variables were $\log _{10}$ transformed to allow a general linear model to be used.

Performance variables were analyzed by means of a multivariate analysis of covariance (MANCOVA) with two factors (species and temperature) and a covariate (size). This analysis generated a number of potential interaction terms: species $\times$ temperature, species $\times$ size, temperature $\times$ size, and species $\times$ temperature $\times$ size. However, several of these interaction terms were nonsignificant and were sequentially removed from the model to address the two main effects (species and temperature). In addition, there was no significant temperature effect (see Results). Thus, for subsequent analyses, temperature data sets were combined for each species.

A series of one-way analyses of covariance were performed on the performance variables to determine which variables contributed to the significant species $\times$ size interaction term observed in the MANCOVA. For two of the performance variables the interaction term was not significant (i.e., the slope of the relationship between size and the performance variable was the same for both species). For these variables, the interaction term was removed to allow a test for potential differences between species.

Finally, we conducted a literature search for studies quantifying escape performance in the lar- 

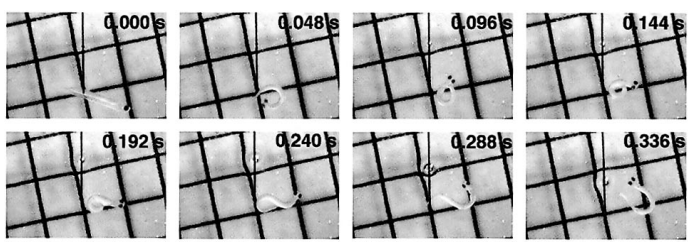

FIGURE 2.-These panels depict a razorback sucker larva being stimulated to perform an escape response. This larva produced a series of O-starts instead of the typical stages of the C-start. Consequently, the center of mass of the larva has moved very little from the first panel to the last panel.

vae of other fish species. Only studies that reported maximum escape response velocity and fish length and that used similar experimental water temperatures were used in this comparison (Webb 1981; Yin and Blaxter 1987; Gibson and Johnston 1995; Hale 1999; Wakeling et al. 1999; Gibb and Dickson 2002). Linear regressions or power functions (depending on the fit used by the researcher) of total length (the size variable common to all studies) versus maximum velocity were compared qualitatively with our data to assess the escape performance of razorback suckers relative to that of other fishes.

\section{Results}

Behavioral Patterns

For the purposes of this study, an escape response consisted of any behavior in response to the stimulus. Among the analyzed escape behaviors, all fish responded to the stimulus by trying to move away rapidly and most performed a $\mathrm{C}$ start (with both stage 1 and stage 2; Figure 1). Stage 3 swimming movements were observed in many, but not all, individuals.

Some razorback sucker individuals performed a behavior we referred to as the O-start. In these cases, the fish would slowly perform the initial C bend and then continue bending to form an $\mathrm{O}$ or $\mathrm{Q}$ shape (Figure 2). The O-start behavior was much more likely to occur in small razorback suckers than in large ones. Razorback suckers weighing $0.001 \mathrm{~g}$ or less had a higher propensity for O-starts ( $21 \%$ of the total escapes) than fish weighing between 0.0011 and $0.002 \mathrm{~g}$ ( $8 \%$ of the total escapes). Further, the smallest razorback suckers $(<0.001 \mathrm{~g})$ only performed complete C-starts (stages 1 and 2) $37 \%$ of the time, whereas slightly larger razorback suckers (0.0011-0.002 g) performed complete $\mathrm{C}$-starts $71 \%$ of the time. The Ostart was not observed in rainbow trout larvae or juveniles.
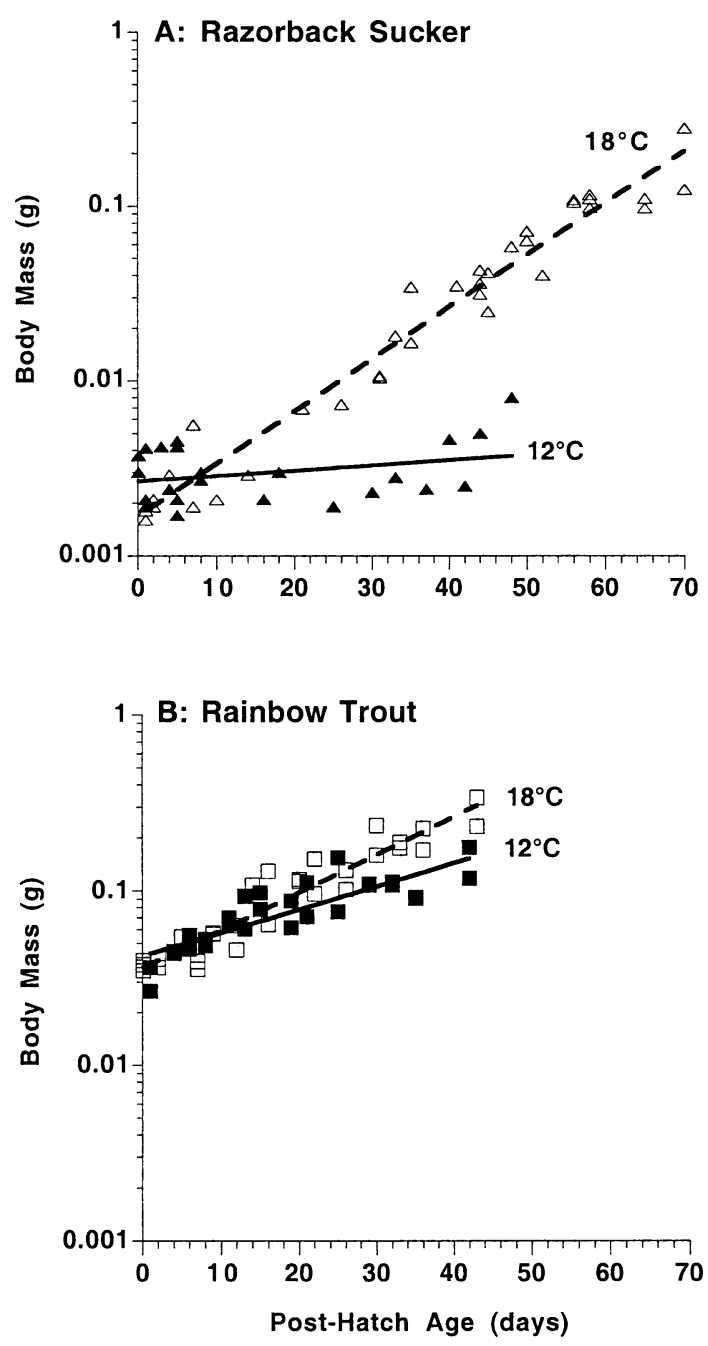

FIGURE 3.-Growth of (A) razorback suckers and (B) rainbow trout during the days after hatching at two temperatures, $18^{\circ} \mathrm{C}$ and $12^{\circ} \mathrm{C}$.

\section{Temperature Effects}

Temperature affected growth rates in both species. The two-way ANCOVA revealed that the three-way interaction term among the two main effects (species and temperature) and the covariate (age) was significant $(F$-value $=33.0, P<0.05)$. This indicates that the species grew differently during the rearing period and responded differently to the temperature treatments. Larvae of a given species reared at $12^{\circ} \mathrm{C}$ and $18^{\circ} \mathrm{C}$ were approximately the same size at hatching, but the $18^{\circ} \mathrm{C}$ fish grew more rapidly in both species (Figure 3A, B). However, this temperature effect was particularly pronounced for the razorback suckers. At $40 \mathrm{~d}$ after hatching, rainbow trout larvae were ap- 
TABLE 1.-Morphological measurements for the ontogenetic series of the razorback suckers and rainbow trout used in this study.

\begin{tabular}{|c|c|c|c|c|c|c|}
\hline \multirow[b]{2}{*}{ Variable } & \multicolumn{3}{|c|}{ Razorback suckers } & \multicolumn{3}{|c|}{ Rainbow trout } \\
\hline & $n$ & Mean $\pm \mathrm{SE}$ & Range & $n$ & Mean $\pm \mathrm{SE}$ & Range \\
\hline Body mass (g) & 61 & $0.030 \pm 0.006$ & $0.002-0.283$ & 57 & $0.098 \pm 0.008$ & $0.027-0.338$ \\
\hline Body mass without yolk sac (g) & 62 & $0.028 \pm 0.006$ & $0.001-0.283$ & 57 & $0.080 \pm 0.009$ & $0.006-0.338$ \\
\hline Total length (cm) & 63 & $1.59 \pm 0.08^{\mathrm{a}}$ & $0.82-3.28^{\mathrm{a}}$ & 57 & $2.35 \pm 0.06^{\mathrm{a}}$ & $1.23-3.28^{\mathrm{a}}$ \\
\hline
\end{tabular}

a Values were adjusted to account for preservation shrinkage by means of an equation from Hjörleifsson and Klein-MacPhee (1992).
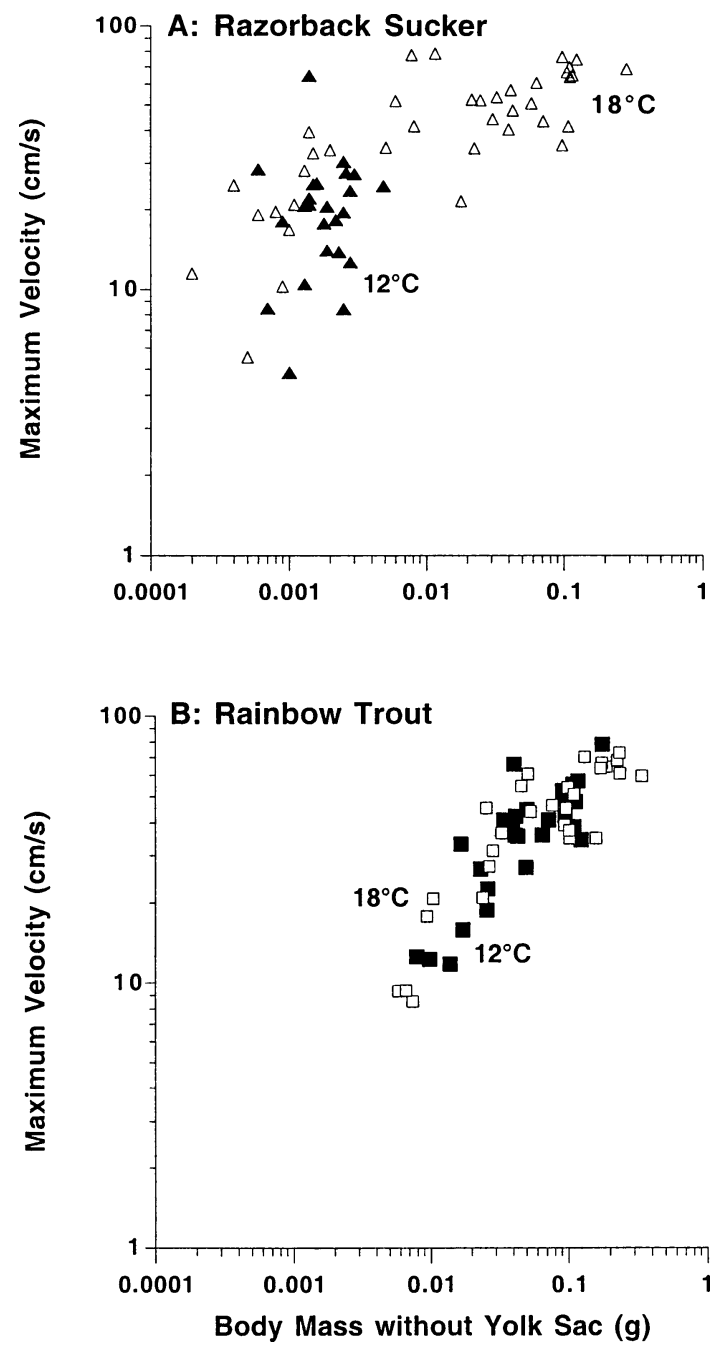

FIGURE 4.-Relationship between body mass without the yolk sac and maximum velocity for (A) razorback suckers and (B) rainbow trout reared at two temperatures. There is no significant difference between the two temperature treatments for either species. proximately $0.15 \mathrm{~g}$ in total body mass at $12^{\circ} \mathrm{C}$ and $0.3 \mathrm{~g}$ at $18^{\circ} \mathrm{C}$ (i.e., twice as large). At the same age, razorback sucker larvae were $0.003 \mathrm{~g}$ at $12^{\circ} \mathrm{C}$ and $0.03 \mathrm{~g}$ at $18^{\circ} \mathrm{C}$ (i.e., 10 times as large). At any given age, young rainbow trout were much larger than young razorback suckers (Figure 3; Table 1).

Results of the preliminary two-way MANCOVA on all four performance variables (using species and temperature as potential effects and size as the covariate) indicated that most interaction terms included in the model were not significant (species $\times$ temperature, temperature $\times$ size, and species $\times$ temperature $\times$ size; all $F$-values $<1.9$ and $P>$ $0.05)$. Thus, these interaction terms were removed from the model. After all nonsignificant interaction terms were removed, there was no significant temperature effect $(F$-value $=1.1, P>0.05)$, but there was a significant species $\times$ size interaction $(F$ value $=3.0, P<0.05$ ). Plots of individual variables supported the findings of the MANCOVA; there was no evidence of a change in performance due to temperature for either species (Figure 4A, B). Because there was no significant temperature effect, data for both temperatures were combined for a given species in all further analyses.

\section{Species Effects}

The significant species $\times$ size interaction found in the two-way MANCOVA suggests that the two species did not respond the same way to changes in body size for some of the performance variables. Thus, a series of one-way ANCOVAs were used as post hoc tests to determine which performance variables contributed to the species $\times$ size interaction found in the MANCOVA. These ANCOVAs revealed that two variables showed a species $X$ size interaction: maximum velocity and maximum acceleration (Table 2), both of which increased with size throughout the developmental period for both species (Figure 5A, B). However, an increase in size affected the two species differently. Small razorback suckers $(<0.04 \mathrm{~g})$ had higher swimming velocities than small rainbow trout $(<0.04 \mathrm{~g})$, but large razorback suckers and large rainbow trout 
TABLE 2.-F-values from one-way ANCOVAs for the potential effects of species and size on escape response variables. Asterisks indicate significance at the 0.05 level. The abbreviation "ns" indicates a nonsignificant interaction term.

\begin{tabular}{lcccc}
\hline \multicolumn{1}{c}{ Variable } & Species & Size & Species $\times$ size & df \\
\hline Maximum velocity & $0.5^{\mathrm{a}}$ & $154.2^{*}$ & $9.5^{*}$ & 1,115 \\
Time to maximum velocity & 2.8 & $14.7^{*}$ & $\mathrm{~ns}$ & 1,115 \\
Maximum acceleration & $6.5^{\mathrm{a}}$ & $29.3^{*}$ & $10.9^{*}$ & 1,112 \\
Time to maximum acceleration & 0.3 & $12.5^{*}$ & $\mathrm{~ns}$ & 1,112 \\
\hline
\end{tabular}

${ }^{a} F$-value not interpreted because of significant interaction term.

$(\geq 0.04 \mathrm{~g}$ ) had similar velocities (Figure 5A). Similarly, small razorback suckers had higher accelerations than small rainbow trout, but large razorback suckers had lower accelerations than large rainbow trout (Figure 5B).

For both timing variables (time to maximum velocity and time to maximum acceleration), the species $\times$ size interaction term was not significant $(F$ value $\langle 2.0, P>0.05$ ). Thus, this term was removed from the ANCOVA model to test for differences between species. After removal of the interaction term, there were no significant differences between the two species with respect to the timing variables (Table 2). Maximum acceleration occurred prior to maximum velocity in both razorback suckers and rainbow trout. Time to maximum velocity and maximum acceleration decreased with size throughout the developmental period for both species (Figure 5C, D). This indicates that both razorback suckers and rainbow trout reach their maximum speed more quickly as they develop. It took razorback sucker and rainbow trout larvae approximately the same amount of time to reach maximum accelerations and velocities.

\section{Comparison of Larval Fish Velocities}

A literature search revealed six species tested under similar water temperatures and with approximately the same size ranges (total length) as the razorback suckers and rainbow trout in our study (Webb and Corolla 1981; Yin and Blaxter 1987; Gibson and Johnston 1995; Hale 1999; Wakeling et al. 1999; Gibb and Dickson 2002). The velocity ranges reported for all eight species (including razorback suckers and rainbow trout) were similar overall (Table 3). At the sizes used in this study, razorback sucker larvae were as fast as those of the other fish species (Figure 6). Rainbow trout
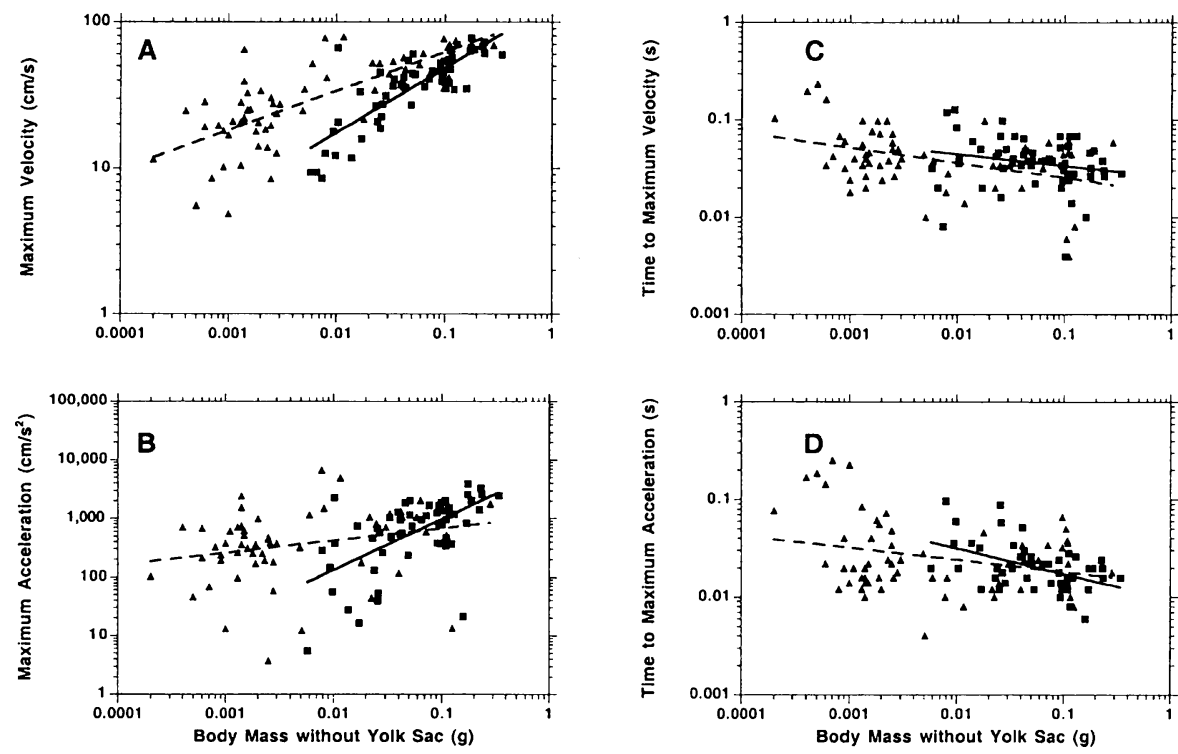

FIGURE 5.- Velocity and acceleration performance variables for the razorback suckers (triangles and dashed lines) and rainbow trout (squares and solid lines) as functions of body mass without the yolk sac. 
TABLE 3.- Velocities and scaling relationships reported for seven teleost species during ontogeny. The variable $y$ is maximum velocity, the variable $x$ total length. See Figure 6 for a graphic depiction.

\begin{tabular}{|c|c|c|c|c|c|}
\hline Study & Species & $\begin{array}{c}\text { Velocity } \\
\text { range }(\mathrm{cm} / \mathrm{s})\end{array}$ & $\begin{array}{l}\text { Length } \\
\text { range }(\mathrm{cm})\end{array}$ & $\begin{array}{c}\text { Water } \\
\text { temperature } \\
\left({ }^{\circ} \mathrm{C}\right)\end{array}$ & Scaling relationship \\
\hline Current study & Razorback sucker & $4.9-78.7$ & $0.82-3.28^{\mathrm{a}}$ & 12 and 18 & $y=26.65 x-4.26$ \\
\hline Current study & Rainbow trout & $8.5-78.1$ & $1.23-3.28^{\mathrm{a}}$ & 12 and 18 & $y=32.70 x-31.02$ \\
\hline Hale 1999 & $\begin{array}{l}\text { Brown trout } \\
\text { Salmo trutta }\end{array}$ & $7.9-52.4^{b}$ & $1.30-2.20$ & 12 & $y=11.91 x^{1.68 \mathrm{c}, \mathrm{d}}$ \\
\hline Gibb and Dickson (2002) & $\begin{array}{l}\text { California halibut } \\
\text { Paralichthys californicus }\end{array}$ & $11.2-79.5$ & $0.63-3.68$ & 18 & $y=24.00 x+1.48$ \\
\hline $\begin{array}{l}\text { Gibson and Johnston } \\
(1995)^{\mathrm{b}}\end{array}$ & $\begin{array}{l}\text { Turbot } \\
\text { Scophthalmus maximus }\end{array}$ & $46.2-100.7$ & $1.70-5.60$ & 18 & $y=28.84 x^{0.74}$ \\
\hline Yin and Blaxter (1987) & $\begin{array}{l}\text { Atlantic herring } \\
\text { Clupea harengus }\end{array}$ & $12.4-29.6$ & $0.88-2.01$ & $8-11$ & \\
\hline Wakeling et al. (1999) & $\begin{array}{l}\text { Common carp } \\
\text { Cyprinus carpio }\end{array}$ & $26.3-56.2^{b}$ & $0.80-6.20$ & 20 & $y=29.74 x^{0.55 \mathrm{e}}$ \\
\hline Webb and Corolla (1981) & $\begin{array}{l}\text { Northern anchovy } \\
\text { Engraulis mordax }\end{array}$ & $6.7-29.6^{b}$ & $0.23-1.33$ & 17 & $y=20.80 x+1.95$ \\
\hline
\end{tabular}

a Values were adjusted to account for preservation shrinkage by means of an equation from Hjörleifsson and Klein-MacPhee (1992).

b Values calculated from reported scaling relationship.

c Reported scaling relationship based on $\log _{10}$-transformed data was recalculated to produce a function describing untransformed data.

$\mathrm{d}$ Units converted from $\mathrm{mm}$ (length) and $\mathrm{m} / \mathrm{s}$ (velocity) to $\mathrm{cm}$ and $\mathrm{cm} / \mathrm{s}$.

e Units converted from $\mathrm{m}$ (length) and $\mathrm{m} / \mathrm{s}$ (velocity) to $\mathrm{cm}$ and $\mathrm{cm} / \mathrm{s}$.

were the second slowest species, only brown trout being slower (Figure 6).

\section{Discussion}

\section{Effects of Temperature}

Our first hypothesis was that razorback suckers and rainbow trout would perform better at $18^{\circ} \mathrm{C}$

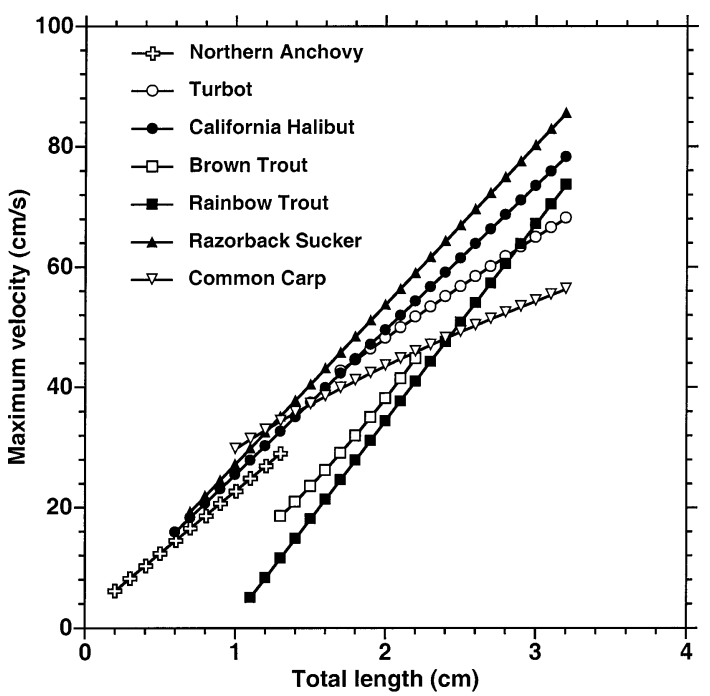

FIGURE 6.- Relationship between maximum velocity and total length based on reported size ranges and scaling relationships for seven species during ontogeny (Webb 1981; Gibson and Johnston 1995; Hale 1999; Wakeling et al. 1999; Gibb and Dickson 2002). See Table 3 for full species descriptions and equation parameters. than at $12^{\circ} \mathrm{C}$ because of the physiological effects of temperature. However, we rejected this hypothesis for both species. Although this result may seem counterintuitive, previous research has shown that extended temperature acclimation (days or weeks) allows changes in metabolic and muscle physiology to occur that compensate for the direct physical and physiological effects of temperature (for a summary, see Schmidt-Nielsen 1997). This compensation can be partial or complete. With partial compensation, cold-acclimated individuals improve in performance during acclimation but never match the performance of the warm-acclimated individuals. With complete compensation, the postacclimation performance of cold-acclimated individuals is indistinguishable from the performance of warm-acclimated individuals (Schmidt-Nielsen 1997).

The results of previous acclimation studies on escape performance in teleost fish species have yielded mixed results (for a review see Temple and Johnston 1997). Some species show no compensation in escape performance after cold acclimation, including larval Atlantic herring (Batty et al. 1993) and adult long-spined sea scorpion Taurulus bubalis (Temple and Johnston 1998). Others show partial compensation, including adult goldfish Carassius auratus (Johnson and Bennett 1995) and adult shorthorn sculpin Myoxocephalus scorpius (Beddow et al. 1995). Still other species show complete or nearly complete compensation, in- 
cluding adult mummichog Fundulus heteroclitus (Johnson and Bennett 1995) and larval and juvenile turbot (Gibson and Johnston 1995). The ability to compensate for a change in temperature is thought to be related to the evolutionary history of the species-a species that is distributed across a latitudinal gradient or experiences temporal changes in temperature is likely to show complete compensation (Temple and Johnston 1997).

In this study, both razorback suckers and rainbow trout demonstrated complete or nearly complete compensation in escape performance after acclimation to $12^{\circ} \mathrm{C}$ and $18^{\circ} \mathrm{C}$. Previous research on adult rainbow trout demonstrated only partial compensation in escape response performance (as assayed by measuring maximum velocity and acceleration during the escape response) when fish were acclimated to lower temperatures $\left(5-10^{\circ} \mathrm{C}\right.$; Webb 1978; Johnson et al. 1996). However, adult rainbow trout demonstrated complete compensation at higher water temperatures $\left(15-25^{\circ} \mathrm{C}\right.$; Webb 1978). It appears that young rainbow trout show acclimation ability similar to that of adults.

The ability of the rainbow trout to compensate across this temperature range is not surprising; this species occurs naturally in North American waters from Alaska to Mexico (Behnke 2002) and can survive a wide range of temperatures (Currie et al. 2000). However, the razorback sucker, which has a much more limited geographic distribution, also showed complete or nearly complete compensation in response to cold acclimation. The razorback sucker may have evolved this compensation mechanism to accommodate the seasonal variation in water temperature that was present in the predam era of the Colorado River (Clarkson and Childs 2000). Historically, juvenile and adult razorback suckers would experience low water temperatures in the winter. However, reproduction occurs in the spring and may be timed to permit larvae to develop in warmer water. Unfortunately, modern razorback sucker populations experience perpetual winter temperatures due to the cold water released from dams into the main-stem Colorado River (Clarkson and Childs 2000).

Although the razorback sucker shows complete physiological compensation in escape performance, temperature indirectly affects performance through its effects on development. After $40 \mathrm{~d}$, razorback suckers reared at $12^{\circ} \mathrm{C}$ were an order of magnitude smaller than those reared at $18^{\circ} \mathrm{C}$. In a recent study investigating the effects of rearing four native Colorado River species, including the razorback sucker, at 10,14 , and $20^{\circ} \mathrm{C}$, Clarkson and Childs (2000) found that the growth rates for all species were significantly lower at colder temperatures. Cold temperatures will also delay development, sometimes extending the larval stage for an entire season or more (Clarkson and Childs 2000). Thus, temperature indirectly affects escape performance because small fish are absolutely slower than larger fish.

An increase in escape performance with size does result in an increase in the ability of larvae to escape predators (Fuiman 1989; Litvak and Leggett 1992). In addition, as larvae develop their sensory systems mature (e.g., their visual acuity improves; Fuiman and Magurran 1994) and this increases their ability to detect and avoid potential predators (i.e., they experience improved "responsiveness"; Fuiman 1994). These patterns have led to a general hypothesis about larval survival, often termed the "bigger-is-better" hypothesis (Litvak and Leggett 1992; Leggett and Deblois 1994). However, research on marine fish larvae suggests that older, bigger larvae actually experience increased predation rates, presumably because they are more likely to attract the attention of potential predators (Litvak and Leggett 1992; Pepin et al. 1992). Thus, the interplay between increasing probability of encountering predators and decreasing probability of capture with size is thought to generate a dome-shaped relationship between size and predator vulnerability whereby fish are predicted to be maximally vulnerable at intermediate sizes.

These findings create a complex prediction about the effects of decreased Colorado River water temperatures on razorback sucker survival. Immediately after hatching, larval razorback suckers may experience reduced predation at colder temperatures because they will remain small and will not attract the attention of fish predators (Fuiman 1989). However, they will experience increased embryonic and larval mortality due to the cold temperatures (Marsh 1985). In addition, the decrease in growth rate due to temperature will delay razorback suckers' attainment of the larger sizes at which they become too fast for predators to catch and too large for them to eat (Fuiman 1994). Because rainbow trout are larger at hatch and grow more rapidly at low water temperatures, they will reach this critical, "predator-proof" size more rapidly than razorback suckers.

\section{Escape Performance Relative to Other Species}

Our second hypothesis was that larval and juvenile escape performance would be poorer in ra- 
zorback suckers than in rainbow trout and other fish species. As we found that the escape performance of razorback suckers was similar to that of rainbow trout during the observed developmental period, we reject this hypothesis. In terms of maximum velocity and acceleration during the escape response, small razorback suckers are faster than small rainbow trout. However, both species had similar performances at larger sizes.

In addition, when compared qualitatively with the larvae of other fish species, the razorback sucker shows similar escape velocities across the size range included in this study. Based on this estimate of performance and the similarity of the escape response between razorback suckers and rainbow trout, we suggest that the escape performance of the razorback sucker is comparable to that of other fish species. However, we note that rainbow trout approached or surpassed the performance of razorback suckers at larger sizes. Thus, although a small razorback sucker may be able to swim faster than a small rainbow trout, any performance advantage is lost as fish grow. Also, if larvae are becoming more obvious to predators and incurring more attacks as they grow, improved swimming speed at larger sizes may be critical to avoiding predation and rainbow trout are improving more rapidly than razorback suckers (i.e., the relationship between size and velocity has a steeper slope). Finally, if the observed relationships between body size and velocity remain constant as these fish grow, then razorback suckers will eventually be slower than rainbow trout (because their escape performance does not increase as rapidly with body size). Thus, rainbow trout will reach speeds at which they can potentially outswim their predators sooner than razorback suckers will.

We also found that razorback suckers and rainbow trout did not differ from one another in the timing of their body movements during the escape response. In fact, both species became absolutely faster at reaching maximum acceleration and velocity as they grew larger. Typically, larger animals take longer to perform physiological functions (Schmidt-Nielsen 1997); thus, this result suggests that escape response performance improves during larval development (Hale 1999). This may be due to developmental changes in the morphology and physiology of the sensory and motor systems that initiate and produce the escape response (Fuiman 1994).

\section{Variability in Escape Response Performance}

The escape performance of the razorback sucker was also affected by the variability in behavior among small-sized fish. Individuals that performed an O-start responded to stimuli by initially bending into a $\mathrm{C}$ shape. However, after the $\mathrm{C}$ formation was reached, the head and the tail of the fish continued to move closer together, causing the fish's body to assume the $\mathrm{O}$ shape. Most fish that performed the $\mathrm{O}$-start followed it with multiple $\mathrm{O}$ bends. This response appeared to be uncoordinated relative to a stereotypical escape response with $\mathrm{C}$ and S-stages.

The presence of the O-start in young razorback suckers may be explained by the fact that they hatch at an early stage of development. Many of their external and internal morphological structures are not fully formed at this time (Minckley and Gustafson 1982). Aberrant escape behaviors may be a consequence of hatching before the developmental process is complete, as the nervous, skeletal, and muscular systems may be too immature to produce a coordinated response. Rainbow trout, in contrast, hatch at an advanced stage of larval development (Ballard 1973), and relatively few morphological changes are completed during posthatch development. Perhaps this is why rainbow trout did not produce $\mathrm{O}$-starts, even at young ages.

The presence of the O-start has clear performance consequences for the razorback sucker. The center of mass moves very little during these Obends, effectively leaving these individuals near the predator for an extended period. Both the occurrence of O-starts and other types of variability in behavior may decrease the effectiveness of the escape response among small razorback suckers.

\section{Summary}

Although razorback suckers show complete compensation in escape response for a decrease in temperature, we suggest that the consistently low water temperatures in the Colorado River will have a negative impact on recruitment for several reasons. First, the mortality of razorback sucker eggs and larvae is higher at low temperatures (Marsh 1985; this study). Second, the presence of the Ostart behavior creates reduced performance in very young individuals and cold water will retard razorback sucker growth and keep them at younger stages for longer periods of time (Clarkson and Childs 2000; this study). Third, reduced growth rates due to temperature will keep razorback sucker larvae and juveniles small, which will prevent them from reaching a critical, predator-proof size. Rainbow trout, in contrast, do not show O-start behavior and their mortality and growth rates are 
not as affected by cold temperatures (Currie et al. 2000; this study). In addition, the faster growth of the rainbow trout at colder temperatures and its rapid improvement in escape performance during development suggest that this species will reach a predator-proof size sooner than the razorback sucker.

Therefore, we conclude that colder water temperatures indirectly diminish razorback sucker escape performance and provide an advantage to introduced coldwater species like the rainbow trout. We concur with the conclusions of previous researchers who have studied the effects of temperature on razorback sucker life history (e.g., Marsh 1985; Clarkson and Childs 2000); it appears that warmer discharges from the dams on the Colorado River (particularly during the spring-summer reproductive period) are necessary to allow successful recruitment of the razorback sucker. However, we realize that increased water temperatures may also benefit nonnative warmwater fishes in the river (Kaeding and Osmundson 1988; Childs and Clarkson 1996). Thus, a complex regime involving nonnative fish removal as well as increased water temperatures will be necessary to reestablish the razorback sucker in the Colorado River.

\section{Acknowledgments}

We thank Carol Chambers, W. Linn Montgomery, and Tad Theimer for their thoughtful advice and contributions to this research. We also recognize Chester Figiel of the U.S. Fish and Wildlife Service for providing razorback sucker eggs and members the of Nishikawa and Gibb laboratories, particularly Kiisa Nishikawa, Jenna Monroy, Kaolin Cummens, and Tammy Frost, for providing assistance, equipment, and laboratory space. We thank Jeff Walker and Alistair Cullum for providing software programs and advice that were essential for the completion of the project. Brook Swanson, Matt O'Neill, Heidie Hornsta, Amy Arnold, Cydney Landels, Kristine Salminen, Tom Johnston, Dennis DeVries, and several anonymous reviewers provided thoughtful comments on the manuscript. This research was funded through two grants awarded to A.C.G., a Northern Arizona University intramural research grant and National Science Foundation grant IBN-0002301.

\section{References}

Andraso, G. M. 1997. A comparison of startle response in two morphs of the brook stickleback (Culaea inconstans): further evidence for a trade-off between defensive morphology and swimming ability. Evolutionary Ecology 11:83-90.

Ballard, W. W. 1973. Normal embryonic stages for salmonid fishes, based on Salmo gairdneri Richardson and Salvelinus fontinalis (Mitchill). Journal of Experimental Zoology 184:7-26.

Batty, R. S., J. H. S. Blaxter, and K. Fretwell. 1993. Effect of temperature on the escape responses of larval herring, Clupea harengus. Marine Biology 115:523-528.

Beddow, T. A., J. L. van Leeuwen, and I. A. Johnston. 1995. Swimming kinematics of fast starts are altered by temperature acclimation in the marine fish Myoxocephalus scorpius. Journal of Experimental Biology 198:203-208.

Behnke, R. J. 2002. Trout and salmon of North America. Free Press, New York.

Bennett, A. F. 1990. Thermal dependence of locomotor capacity. American Journal of Physiology 259: R253-R258.

Blinn, D. W., C. Runck, D. A. Clark, and J. N. Rinne. 1993. Effects of rainbow trout predation on little Colorado spinedace. Transactions of the American Fisheries Society 122:139-143.

Bozek, M. A. 1984. Factors affecting the reproductive success of razorback suckers and bonytail chubs in Lake Mohave, Arizona-Nevada during 1982-1983. Master's thesis. University of Nevada, Las Vegas.

Bulkley, R. V., and R. Pimentel. 1983. Temperature preference and avoidance by adult razorback suckers. Transactions of the American Fisheries Society 11:601-607.

Childs, M. R., and R. W. Clarkson. 1996. Temperature effects on swimming performance of larval and juvenile Colorado squawfish: Implications for survival and species recovery. Transactions of the American Fisheries Society 125:940-947.

Clarkson, R. W., and M. R. Childs. 2000. Temperature effects of hypolimnial-release dams on early life stages of Colorado River basin big-river fishes. Copeia 2000:402-412.

Cullum, A. J. 1999. Didge: image digitizing software. Parthenogenetic Products. Creighton University, Omaha, Nebraska.

Currie, R. J., W. A. Bennet, and T. L. Beitinger. 2000. Critical thermal minima and maxima of three freshwater game-fish species acclimated to constant temperature. Environmental Biology of Fishes 51:187200.

Fuiman, L. A. 1989. Vulnerability of Atlantic herring larvae to predation by yearling herring. Marine Ecology Progress Series 51:291-299.

Fuiman, L. A. 1994. The interplay of ontogeny and scaling in the interactions of fish larvae and their predators. Journal of Fish Biology 45(Supplement A):55-79.

Fuiman, L. A., and A. E. Magurran. 1994. Development of predator defenses in fishes. Reviews in Fish Biology and Fisheries 4:145-183.

Gibb, A. C., and K. A. Dickson. 2002. Functional morphology and biochemical indices of performance: is there a correlation between metabolic enzyme 
activity and swimming performance? Integrative and Comparative Biology 42:199-207.

Gibson, S., and I. A. Johnston. 1995. Scaling relationships, individual variation, and the influence of temperature on maximum swimming speed in early settled stages of the turbot Scophthalmus maximus. Marine Biology 121:401-408.

Hale, M. E. 1999. Locomotor mechanics during early life history: effects of size and ontogeny on faststart performance of salmonid fishes. Journal of Experimental Biology 202:1465-1479.

Hartman, G. F. 1965. The role of behavior in the ecology and interaction of underyearling coho salmon (Oncorhynchus kisutsch) and steelhead trout (Salmo gairdneri). Journal of the Fisheries Research Board of Canada 22:1035-1081.

Hjörleifsson, E., and G. Klein-MacPhee. 1992. Estimation of live standard length of winter flounder Pleuronectes americanus larvae from formalin-preserved, ethanol-preserved, and frozen specimens. Marine Ecology Progress Series 82:13-19.

Horn, M. J., P. C. Marsh, G. Mueller, and T. Burke. 1994. Predation by odonate nymphs on larval razorback suckers (Xyrauchen texanus) under laboratory conditions. The Southwestern Naturalist 39:371-374.

Jenkins, T. M. 1969. Social structure, position choice, and microdistribution of two trout species, Salmo trutta, and Salmo gairdneri, resident in mountain streams. Animal Behavior Monographs 2:57-123.

Johnson, J. E., M. G. Pardew, and M. M. Lyttle. 1993. Predator recognition and avoidance by larval razorback sucker and northern hog sucker. Transactions of the American Fisheries Society 122:1139_ 1145 .

Johnson, T. P., and A. F. Bennett. 1995. The thermal acclimation of burst escape performance in fish: an integrated study of molecular and cellular physiology and organismal performance. Journal of Experimental Biology 198:2165-2175.

Johnson, T. P., A. F. Bennett, and J. D. McLister. 1996. Thermal dependence and acclimation of fast start locomotion and its physiological basis in rainbow trout (Oncorhynchus mykiss). Physiological Zoology 69:276-292.

Kaeding, L. R., and D. B. Osmundson. 1988. Interaction of slow growth and increased early-life mortality: a hypothesis on the decline of Colorado squawfish in the upstream regions of its historic range. Environmental Biology of Fishes 22:287-298.

Karjalainen, J. 1992. Effects of different preservation methods on total length and weight of larval vendace (Coregonus albula [L.]). Nordic Journal of Freshwater Research 67:88-90.

Katzir, G., and J. M. Camhi. 1993. Escape response of black mollies (Poecilia sphenops) to predatory dives of a pied kingfisher (Ceryle rudis). Copeia 1993: 549-553.

Leggett, W. C., and E. Deblois. 1994. Recruitment in marine fishes: is it regulated by starvation and predation in the egg and larval stages? Netherlands Journal of Sea Research 32:119-134.

Litvak, M. K., and W. C. Leggett. 1992. Age and size- selective predation on larval fishes: the bigger is better hypothesis revisited. Marine Ecology Progress Series 81:13-24.

Marsh, P. C. 1985. Effect of incubation temperature on survival of embryos of native Colorado River fishes. Southwestern Naturalist 30:129-140.

Marsh, P. C., and J. E. Brooks. 1989. Predation by ictalurid catfishes as a deterrent to re-establishment of hatchery-reared razorback suckers. Southwestern Naturalist 34:188-195.

Marsh, P. C., and D. R. Langhorst. 1988. Feeding and fate of wild larval razorback sucker. Environmental Biology of Fishes 2:59-67.

Marsh, P. C., and W. L. Minckley. 1989. Observations Aon recruitment and ecology of razorback sucker: Lower Colorado River, Arizona-California-Nevada. Great Basin Naturalist 49:71-78.

McCarthy, M. S. 1986. Age of imperiled razorback sucker (Pisces, Catostomidae) from Lake Mohave, Arizona-Nevada. Master's thesis. Arizona State University, Tempe.

McCarthy, M. S., and W. L. Minckley. 1987. Age estimation for razorback sucker (Pisces: Catostomidae) from Lake Mohave, Arizona and Nevada. Journal of the Arizona-Nevada Academy of Science 21: 87-97.

Minckley, W. L. 1983. Status of the razorback sucker, Xyrauchen texanus (Abbott), in the lower Colorado River Basin. Southwestern Naturalist 28:165-187.

Minckley, W. L., and E. S. Gustafson. 1982. Early development of the razorback sucker, Xyrauchen texanus (Abbott). Great Basin Naturalist 42:553-561.

Minckley, W. L., P. C. Marsh, J. E. Brooks, J. E. Johnson, and B. L. Jensen. 1991. Management toward recovery of the razorback sucker. Pages 303-358 in W. L. Minckley and J. E. Deacon, editors. Battle against extinction: native fish management in the American West. University of Arizona Press, Tucson.

Mueller, G. 1989. Observations of spawning razorback sucker (Xyrauchen texanus) utilizing riverine habitat in the lower Colorado River, Arizona-Nevada. Southwestern Naturalist 34:147-149.

Pepin, P., T. H. Shears, and Y. de Lafontaine. 1992. Significance of body size to the interaction between a larval fish (Mallotus villosus) and a vertebrate predator (Gasterosteus aculeatus). Marine Ecology Progress Series 81:1-12.

SAS Institute. 1998. Statview, 2nd edition. SAS Institute, Cary, North Carolina.

Schmidt-Nielsen, K. 1997. Animal physiology: adaptation and environment. Cambridge University Press, Cambridge, UK.

Seale, D. B., and F. P. Binkowski. 1988. Vulnerability of early life intervals of Coregonus hoyi by a freshwater mysid, Mysis relicta. Environmental Biology of Fishes 21:117-125.

Shields, P. A., and S. R. Carlson. 1996. Effects of formalin and alcohol preservation on lengths and weights of juvenile sockeye salmon. Alaska Fishery Research Bulletin 3:81-93.

Sigler, W. F., and J. W. Sigler. 1996. Fishes of Utah: a 
natural history. University of Utah Press, Salt Lake City.

Swain, D. P. 1992a. The functional basis of natural selection for vertebral traits of larvae in the stickleback Gasterosteus aculeatus. Evolution 46:987997.

Swain, D. P. 1992b. Selective predation for vertebral phenotype in Gasterosteus aculeatus: reversal in the direction of selection at different larval sizes. Evolution 46:998-1013.

Temple, G. K., and I. A. Johnston. 1997. The thermal dependence of fast-start performance in fish. Journal of Thermal Biology 22:391-401.

Temple, G. K., and I. A. Johnston. 1998. Testing hypotheses concerning the phenotypic plasticity of escape performance in fish of the family Cottidae. Journal of Experimental Biology 201:317-331.

Tyus, H. M., B. D. Burdick, R. A. Valdez, C. M. Hayton, T. A. Lytle, and C. R. Berry. 1982. Fishes of the upper Colorado River basin: distribution, abundance, and status. Pages 12-70 in W. H. Miller, H. M. Tyus, and C. A. Carlson, editors. Fishes of the upper Colorado River system: present and future. American Fisheries Society, Western Division, Bethesda, Maryland.

Vanicek, C. D., R. H. Kramer, and D. R. Franklin. 1970. Distribution of Green River fishes in Utah and Colorado following closure of Flaming Gorge Dam. Southwestern Naturalist 14:297-315.
Wakeling, J. M., K. M. Kemp, and I. A. Johnston. 1999. The biomechanics of fast-starts during ontogeny in the common carp Cyprinus carpio. Journal of Experimental Biology 202:3057-3067.

Walker, J. A. 1997. QuickSAND: quick smoothing and numerical differentiation for the Power Macintosh. Field Museum of Natural History, Chicago, Illinois.

Walker, J. A. 1998. Estimating velocities and accelerations of animal location: a simulation experiment comparing numerical differentiation algorithms. Journal of Experimental Biology 201:981-995.

Webb, P. W. 1978. Temperature effects on acceleration of rainbow trout, Salmo gairdneri. Journal of the Fisheries Research Board of Canada 35:1417-1422.

Webb, P. W. 1981. Responses of Northern anchovy, Engraulis mordax, larvae to predation by a biting plantktivore, Amphiprion percula. U.S. National Marine Fisheries Service Fishery Bulletin 79:727735.

Webb, P. W. and R. T. Corolla. 1981. Burst swimming performance of northern anchovy, Engraulis mordax, larvae. U.S. National Marine Fisheries Service Fishery Bulletin 79:143-150.

Weihs, D. 1973. The mechanism of rapid starting of slender fish. Biorheology 10:343-350.

Yin, M. C., and J. H. S. Blaxter. 1987. Escape speeds of marine fish larvae during early development and starvation. Marine Biology 96:459-468. 